GLOBAL JOURNAL OF EDUCATIONAL RESEARCH VOL 16, 2017: 149-153

COPYRIGHT@ BACHUDO SCIENCE CO. LTD PRINTED IN NIGERIA. ISSN 1596-6224 www.globaljournalseries.com; Info@globaljournalseries.com

\title{
GENDER AS PREDICTOR OF ACADEMIC ACHIEVEMENT IN ENGLISH AMONG SENIOR SECONDARY SCHOOL TWO STUDENTS IN CALABAR METROPOLIS, CROSS RIVER STATE
}

R. F. ATTAH AND P. M. ITA

(Received 17, August 2017; Revision Accepted 13, September 2017)

\begin{abstract}
The study examined the influence of gender on academic achievement in English Language among senior secondary school students in Calabar metropolis, Cross River State. The researchers adopted survey designfor the study. The study sample comprise 660 Senior Secondary School two (SSS II) students drawn from 22 public secondary schools, 15 in Calabar Municipality and seven (7) public secondary schools in Calabar South Local Government Area, Cross River State, using Stratified Random and Purposive sampling techniques. Data were generated through "English Language Academic Achievement Rating Scale" (ELAARS). A reliability index of 0.75 was realized using Cronbach's alpha. The data generated were analysed using Independent t-test at 0.05 level of significance. The result of the analysis showed that gender has no significantly influence on academic performance in English Language among senior secondary school students in Calabar metropolis.
\end{abstract}

KEYWORDS: Gender, predictor, academic achievement, English language.

\section{INTRODUCTION}

Despite the importance attached to the English Language, and efforts made by stake holders in the educational sector to optimize the learning of English Language as a school subject, students' achievement in English Language has not commensurate to the investment made in it. There has been a fall in students' academic achievement in English Language over the years as compared to other subjects in the school system. Evidence abounds that students have not been doing well in English Language. Adeosun (2010) observed that the low standard of English Language is reflected in the large number of candidates who failed the school certificate English. Eme (2012) revealed that $67.43 \%, \quad 60.56 \%, \quad 53.79 \%$ and $41.82 \%$ of students who sat for this examination failed in 2001, 2002, 2003 and 2004 respectively. Also the result of the SSCE from 2012 to 2014 showed that 2012 (38.81\%), $2013(36.57 \%)$ and $2014(31.28 \%)$ respectively passed the subject at least at credit level (West Africa Examination Council 2014). From the result, it has shown a drastic decline in the achievement of students in the subject. This statistics and report is a call for concern for any patriotic stakeholder in the education subsector to ponder over the system.

According to Fakeye (2011), Nigerian secondary school students have problems in the learning of English Language as revealed in their achievement in the public examinations. Therefore, this situation is a source of concern, and has aroused the interest of these researchers to investigate possible causes of lapses in the effective learning of English Language. Many likely factors may be responsible for these students' poor academic achievement in the subject. Researchers such as

R. F. Attah, Department of Arts Education, University of Calabar, Calabar, Cross River State, Nigeria.

P. M. Ita, Department of Arts Education, University of Calabar, Calabar, Cross River State, Nigeria. 
Eme (2012) and Obanya (2013) have pointed out some factors such as the teacher, the school and the home environment. Others are peer group influence, pedagogical variables, government policies among others. However, in view of the entrenched gender practices in Nigeria and cross River State, particularly, an investigation of the role of gender is still valid. Consequently, the pertinent question that this researcher sought to answer is: does gender differentials, influence students' academic achievement in English Language?

Gender has been regarded as an important affective factor that plays a specific role and influences second language acquisition, (Zoghi, Kazemi \& Kalan 2013). In a study on students' personal variables as correlates of academic achievement in English as a second language in Lagos State, Nigeria, Fakeye (2011) investigated the relationship between students' personal variables and achievement in English Language. Questionnaire on 'Students' Attitude to English" (QSAE) and "Students' Academic Ability Test" (SAAT) were used for data collection. A sample of four hundred 400) Senior Secondary school studentswere randomly selected from five (5) secondary schools for the study. A correlational analysis and a t-test were run on the variables and the students' annual scores in English. The analyses revealed that the difference between male and female students' achievements in English Language was not significant. (T-value 0.305 , degree of freedom was 398 and $p>05)$. There have been a number of other empirical studies on the same subject matter by different researchers in different places using different samples and methodology but still came to the same conclusion that gender has no significant influence on academic achievement of students in English Language (Okoye (2009);Obadaki (2011); Babalola and Onyiloye (2012); Adeyemi and Adeyemi; (2013) Adeyemi (2014).

However, Zoghi, Kazemi and Kalan (2013) in a related study examined the effect of gender on English as a foreign language (EFL) in Iran Language Institute (ILS) using100 students (50 males and 50 females) selected from four different classes. The ages of the participants range between 12 and 14 years. The employed procedures were quantitative methods of analysis and making use of descriptive analysis, pair t-test, and the effect size. The total average of the female students $(M=13.18)$ is higher than that of males' $(M=11.47)$. Female students outperformed the male students. In this case, female students had a standard deviation of 3.20 whereas males had achieved a standard deviation of 3.54. It shows the amount of variation within scores was smaller in females than males. This produced a t-value of -3.928 and a $p$-value of .000 , which is less than the .05 significant level. The results indicated that English as a Foreign Language learning is to some extent related to gender and it has a significant effect on the achievement test. This conclusion was earlier adopted by Bidin and Jusof (2012).

\section{Purpose of the study}

The purpose of this study therefore was to examine the influence of gender on academic achievement in English Language among senior secondary school two (SSS11) students in Calabar metropolis, Cross River State.

\section{Research question}

To what extent does students' gender influence academic achievement in English Language in the research area?

\section{Statement of hypothesis}

There is no significant influence of gender (male and female) on students' academic achievement in English Language.

\section{Methodology}

The study was survey research, in Calabar metropolis, Cross River State. The population of this study comprised all the second year students in Senior Secondary School (SSS II) in the 22 public (mixed) secondary schools in Calabar Metropolis totaling 5,020 students (2719 males, 2301 females). Out of that number, a sample of 660 students (351 Males, 309 Females) was drawn constituting $20 \%$ of the population through the stratified Random Sampling. The stratification was based on gender. This was to ensure that both male and female students were adequately represented in the study. The purposive sampling technique was used to select schools for the study on the basis of the most populated schools. Consequently, 12 most populated secondary schools were selected and used for the study. This is shown in Tables 1\& 2. Data were generated through "English Language Academic Achievement Rating Scale" (ELAARS). A reliability index of 0.75 was achieved using Cronbach's alpha. The data generated were analysed using Independent ttest at 0.05 level of significance. 
Table 1: Distribution of students in senior secondary schools two (SS II) by sex and Local Government areas in Calabar Metropolis of Cross River State

\begin{tabular}{|c|c|c|c|c|c|}
\hline $\mathrm{S} / \mathrm{N}$ & LGA & No. of Schools & $\begin{array}{l}\text { No. of } \\
\text { in SS }\end{array}$ & Students & $\begin{array}{l}\text { Total Population } \\
\text { of Students }\end{array}$ \\
\hline 1 & $\begin{array}{l}\text { Calabar } \\
\text { Municipality }\end{array}$ & 15 & $\begin{array}{l}\text { Male } \\
1721\end{array}$ & $\begin{array}{l}\text { female } \\
1417\end{array}$ & 3,138 \\
\hline 2. & $\begin{array}{l}\text { Calabar South } \\
\text { Total }\end{array}$ & $\begin{array}{c}7 \\
22\end{array}$ & $\begin{array}{l}998 \\
2719\end{array}$ & $\begin{array}{l}884 \\
2301\end{array}$ & $\begin{array}{l}1,882 \\
5,020\end{array}$ \\
\hline
\end{tabular}

Source: Cross River State Secondary Education Planning, Research and Statistics unit. (2014)

Table 2: Sample distribution of students in selected schools on gender

\begin{tabular}{cccccl}
\hline Sample schools & Local Government Area & Population & Male & Female & Sample \\
\hline A & Calabar South & 270 & 36 & 18 & 54 \\
B & Calabar South & 360 & 38 & 34 & 72 \\
C & Calabar South & 290 & 23 & 35 & 58 \\
D & Calabar South & 264 & 29 & 24 & 53 \\
E & Calabar South & 309 & 36 & 25 & 61 \\
F & Calabar South & 239 & 28 & 21 & 49 \\
G & Calabar Municipality & 225 & 23 & 22 & 45 \\
H & Calabar Municipality & 236 & 29 & 18 & 47 \\
I & Calabar Municipality & 231 & 25 & 21 & 46 \\
J & Calabar Municipality & 295 & 31 & 28 & 59 \\
K & Calabar Municipality & 339 & 35 & 32 & 67 \\
L & Calabar Municipality & 245 & 18 & 31 & 49 \\
& Total & 3303 & 351 & 309 & 660
\end{tabular}

Source: Cross River State Secondary Education Planning, Research and Statistics Unit. (2014)

\section{PRESENTATION OF RESULT}

HO: There is no significant influence of gender (Male and female) on students' academic achievement in English Language.

The independent variable in this hypothesis is students' gender while the dependent variable is academic achievement in English Language. The students' gender was categorized into male and female. So the hypothesis was tested to verify the influence of students' gender on their academic achievement in English Language. The independent t-test was employed to test for significance. The result of the analysis is presented in Table 3.
The result on table 3 shows the English Language academic achievement mean score and standard deviation for the two groups of respondents. The mean score of female students was slightly higher than male students $(12.99>12.65)$. This produced calculated $t$-value of 1.05 which is lower than the critical t-value of 1.96 at 0.05 significance level with 638 degree of freedom. This implies that gender did not exert significant influence on the academic achievement of students in English Language. In other words, male and female students do not differ significantly in their academic performance in English Language. Therefore, the null hypothesis was upheld while the alternate was rejected. 
Table 3: Result of independent t-test analysis of the influence of gender on

\begin{tabular}{|c|c|c|c|c|c|c|c|}
\hline $\begin{array}{l}\text { Dependent } \\
\text { Variable }\end{array}$ & Independent Variable Gender & $\mathrm{N}$ & Mean & SD & Df & t-cal & \\
\hline & Male & & 341 & 12.65 & 4.21 & 638 & 1.05 \\
\hline $\begin{array}{l}\text { Academic } \\
\text { achievement } \\
\text { of students }\end{array}$ & Female & & 299 & 12.99 & 3.99 & & \\
\hline
\end{tabular}

$\mathrm{N}=640, \mathrm{P}>.05$, not significant, critical t-value $=1.96$

\section{DISCUSSION OF FINDINGS}

It was hypothesized that gender of students' has no significant influence on their academic achievement in English. The data analysis revealed that gender does not significantly influence academic achievement in English Language. This finding corroborated the findings by Fakeye (2011) as well as those of Adeyemi and Adeyemi (2013) which revealed that the difference between male and female students' academic achievements in English Language was not significant.The findings also cohere with that of Babalola and Onyiloye (2012) where they found out that gender had no significant influence on students' ability to acquire the tools of language of communication.

The findings of this research work portray the prevalent social dynamics, where men and women equally struggle for survival in a competitive world. The advancement in technology and gender targeted programmes have made parents drop some of the stereotypes that prevented them from encouraging the girl child aspirations. The increased access to electronic media like television and internet has exposed both girls and boys to language stimuli and models that help narrow the disparity that would have existed because of gender. Therefore, if male and female students put in effort to study, they can succeed irrespective of their gender.

However, this research work contradicts those of Zoghi, Kazemi and Kalan (2013), Bidin and Jusof (2012) who studied the influence of gender and social economic status on boarding school students' English Language performance. On the whole, the finding that gender of students did not influence learning outcomes in English Language implies that all variables under control, the males will not perform better than females. This could be because the subject area does not involve much analytical skills like the sciences where males have performed significantly better.

\section{CONCLUSION}

Based on the findings of the study, it can be concluded that students' gender is significant to their achievement in English language.

\section{Recommendation}

Based on the findings of this study, the following recommendation is made:

The English Language teachers should evolve effective teaching and learning strategies for English Language to develop the students. The teachers should treat and handle the students equally, giving room for individual differences not necessarily gender. Teachers should learn to appreciate the students' peculiar problems and help them especially as regards their study patterns.

\section{REFERENCES}

Adeosun, S., 2010. Prior-language experience and whole language approach as determinants of success in reading. Unpublished Ph.D., Thesis, University of Ibadan.

Adeyemi, B. A and Adeyemi, B. B., 2013. A comparative study of secondary school students' performance in English and 
Social Studies in Junior Secondary Schools in Osun State, Nigeria. Research on Humanities and Social Sciences. 3, (7): 121-125.

Adeyemi, S. B., 2014. The effect of gender on secondary school students' achievement in map work. European Journal of Educational Studies 6,(1): 21-31.

Babalola, O and Onyiloye, G. O., 2012. Language and gender distinctions. International Review of Social Sciences and Humanities. 2, (2), 236-242.

Bidin, S and Jusof, K., 2012. The Influence of gender and social economic status on boarding school students' English Language performance. Canadian Social Science 5, (5): 41-47.

Eme, U. J., 2012. School variables and English studies achievement among students in Akwa Ibom state. Journal of Educational and Social Research, 2, (3): 33-38.

Fakeye, D. O., 2011. Students' personal variables as correlates of academic achievement in English as a second language in Nigeria. Journal of Social Sciences, 22, (3): 205-211.
Obadaki, Y. Y., 2011. A Comparative study of gender difference performance in geography: a case study of some selected schools in Zaria inspectorate division of Kaduna State. A Paper Presented at the 46th Annual Conference of the Science Association of Nigeria (SAN) Held at Ahmadu Bello University, Zaria, Nigeria from 24th-28th July, 2011.

Obanya, P. A. I., 2013. Thinking, talking and education. Ibadan: Evans Brothers (Nigeria ,Publishers) Limited.

Okoye, N. N. (2009). The Psychology of effective learning, Ibadan, Department of Guidance and Counseling.

Zoghi, M., Kazemi, S and Kalani, A., 2013. The Effect of Gender on Language Learning. Journal of Novel Applied Sciences 2 (S4). 1124-1128. 